\title{
MACRONUTRIENT CONCENTRATION AND CONTENT IN PASSION FRUIT LEAVES UNDER SAMPLING METHODS AND N-K FERTILIZATION RATES ${ }^{1}$
}

\author{
RODINEI FACCO PEGORARO², PAULO AUGUSTO PEREIRA LOPES 3 , \\ DEIVISSON FERREIRA DA SILVA ${ }^{4}$, VICTOR MARTINS MAIA ${ }^{5}$, ANANIAS COSTA MEDEIROS ${ }^{6}$
}

ABSTRACT - Nitrogen and potassium fertilization and assessment of adequate nutritional status are essential for increasing fruit production of passion fruit. However, studies related to characterization of the leaf nutrient concentration and content in passion fruit with different production capacities are scarce in the literature in Brazil. The objective of this study was to evaluate macronutrient leaf concentration and content in different parts of the reproductive shoot of yellow passion fruit subjected to different ratios of $\mathrm{N}$ and $\mathrm{K}$ fertilization. The study was conducted in a randomized block design, with three replications, following a 4 x 6 factorial arrangement consisting of four cultivars of yellow passion fruit (BRS Gigante Amarelo, IAC 275, BRS Ouro Vermelho, and BRS Sol do Cerrado) and six application rates of $\mathrm{N}-\mathrm{K}_{2} \mathrm{O}$ fertilizer (0-0, $50-125,100-250,150-375,200-500$, and 250-625 kg ha-1 year-1). Two leaf sampling methods were adopted (leaf located at a position adjacent to the fruit, and leaf located at the end of the reproductive branch) for nutritional assessment. The leaf located at the adjacent position had lower $\mathrm{N}, \mathrm{P}, \mathrm{K}, \mathrm{Mg}$, and $\mathrm{S}$ concentration and higher Ca concentration than the concentrations observed in the standard leaf. However, the higher leaf dry matter in adjacent leaves resulted in increased macronutrient concentration/content. The increase in $\mathrm{N}-\mathrm{K}$ fertilizations inhibited $\mathrm{Ca}$ and $\mathrm{Mg}$ content in the leaves adjacent to the fruit of the Gigante Amarelo, IAC, and Ouro Vermelho passion fruit cultivars, but did not affect $\mathrm{Ca}$ and $\mathrm{Mg}$ content in the standard leaf. The passion fruit cultivars showed different leaf nutrient contents after $\mathrm{N}-\mathrm{K}$ fertilization, indicating variable nutritional demands and the need for specific diagnostic methods for each cultivar.

Index terms: Passiflora edulis Sims f. flavicarpa Deg; Nutrient content; Mineral nutrition; Cultivars.

\section{TEOR E ACÚMULO DE MACRONUTRIENTES EM FOLHAS DE MARACUJAZEIRO SOB MÉTODOS DE AMOSTRAGEM E ADUBAÇÕES N-K}

\begin{abstract}
RESUMO - A adubação nitrogenada e potássica e a avaliação adequada do estado nutricional são imprescindíveis para o aumento da produção de frutos de maracujá, no entanto, são consideradas escassas no Brasil informações literárias relacionadas à caracterização dos teores e acúmulos foliares de nutrientes em maracujazeiros com distintas capacidades produtivas. Objetivou-se avaliar os teores e acúmulos foliares de macronutrientes em partes distintas do ramo frutífero de cultivares de maracujazeiro-azedo submetidos à adubação com $\mathrm{N}$ e K. O delineamento utilizado foi em blocos casualizados, com três repetições, no esquema fatorial $4 \times 6$, consistindo de quatro cultivares de maracujazeiro azedo (BRS Gigante Amarelo, IAC 275, BRS Ouro Vermelho e BRS Sol do Cerrado) e seis doses de N-K $\mathrm{O}_{2}(0-0,50-125,100-250,150-375,200-500$ e 250-625 kg ha-1 ano ${ }^{-1}$ ). Foram adotados dois métodos de amostragem foliar (folha localizada na posição adjacente ao fruto e folha localizada no final do ramo frutífero) para a avaliação nutricional. A maior produção de massa de matéria seca implicou em maiores acúmulos médios de macronutrientes nas folhas adjacentes das cultivares de maracujazeiro. O aumento das adubações com N-K inibiu o acúmulo de $\mathrm{Ca}$ e $\mathrm{Mg}$ nas folhas adjacentes ao fruto para as cultivares Gigante Amarelo, IAC e Ouro Vermelho, mas não alteraram o acúmulo de $\mathrm{Ca}$ e $\mathrm{Mg}$ na folha localizada no final do ramo frutífero. As cultivares de maracujazeiro apresentaram distintos acúmulos foliares de macronutrientes após a adubação com N-K, indicando a presença de demanda nutricional variável e necessidade de elaboração de métodos de diagnose específicos para cada cultivar.
\end{abstract}

Termos para indexação: Passiflora edulis Sims f. flavicarpa Deg; Conteúdo de nutrientes; Nutrição mineral; Cultivares.

\footnotetext{
1(Paper 033-16). Received February 22, 2016. Accepted August 24, 2016.

${ }^{2}$ Agronomist, D.Sc., Professor of the Instituto de Ciências Agrárias, Universidade Federal de Minas Gerais. Avenida Universitária, 1.000 - Bairro Universitário - Montes Claros - MG - CEP: 39.404-547. Brazil. *Corresponding author. E-mail: rodinei_pegoraro@yahoo.com.br ${ }^{3}$ Agronomist, Master's degree student in Plant Production in the Semiarid Region, Unimontes, Janaúba-MG, Brazil. E-mail: paulo_ ap117@hotmail.com

${ }^{4}$ Agronomist, Professor of the Instituto Federal Catarinense, Rodovia BR 280, km 27, Porto Grande, Araquari, Santa Catarina, CEP 89245-000. E-mail: deivisson.silva@ifc.edu.br

${ }^{5}$ Agronomist, Dr., Professor in the Agrarian Sciences Department, Unimontes,Janaúba-MG, Brazil. E-mail: victor.maia@unimontes.br ${ }^{6}$ Agronomist of the Consórcio União da Serra Geral company, Janaúba, MG, Brazil. E-mail: ananias.medeiros@hotmail.com
} 


\section{INTRODUCTION}

Passion fruit (Passiflora edulis) is a fruit-bearing plant of great economic and social importance for Brazil, which is the largest producer and consumer of its in natura and processed fruit juice in the world. In 2014, the cultivated area for this plant in Brazil was 57,183 ha, obtaining production of $823,284 \mathrm{t}$ of fruit and mean yield of $14.5 \mathrm{t} \mathrm{ha}^{-1}$ (IBGE, 2016). This production is very dependent on balanced fertilization and adequate leaf nutrient concentrations.

Nitrogen and potassium are the macronutrients most in demand by passion fruit (BORGES et al., 2002; CAVALCANTE et al., 2012). N participates in the structure of amino acids, proteins, vitamins, chlorophyll, enzymes, and coenzymes, acting mainly in the processes of ionic absorption, photosynthesis, respiration, synthesis, and vegetative growth (TAIZ; ZEIGER, 2013). N deficiency in passion fruit plants leads to generalized chlorosis and early leaf drop, flowers with light red color, and light yellow fruits with a translucent appearance (FREITAS et al., 2011).

$\mathrm{K}$ is essential in osmotic regulation, protein synthesis and stability, permeability of the plasma membrane, fruit formation, and soluble solids production (TAIZ; ZEIGER, 2013). K deficiency can lead to problems such as lower concentration of total soluble solids and of vitamin $\mathrm{C}$ in the fruit and to reduced fruit production (FREITAS et al., 2006). The literature reports that $\mathrm{K}$ is one of the elements most responsible for fruit quality in passion fruit (AULAR et al., 2014).

Leaf diagnosis is an important technique for evaluating the nutritional state of the passion fruit plant. Nevertheless, various factors affect leaf nutrient concentrations and content, such as the age of the leaf, the position of the leaf on the branch, the phenological phase, and the productive capacity of the cultivar (FREITAS et al., 2007), as well as the nutrient source used in fertilization (SOUZA et al., 2013). In this regard, Santos et al. (2011) observed N leaf concentrations ranging from 3.0 to $6.3 \mathrm{dag} \mathrm{kg}^{-1}$ depending on nitrogen fertilization and the time of harvest (66 to 127 days after planting). Furthermore, Sousa et al. (2013) found that the species Passiflora edulis had higher leaf concentrations of $\mathrm{N}, \mathrm{P}, \mathrm{K}$, and $\mathrm{Ca}$, and the species $P$. ligularis had the highest leaf concentration of $\mathrm{Mg}$.

Fertilization with unsuitable application rates of $\mathrm{N}$ and $\mathrm{K}$ can alter macronutrient uptake by passion fruit. Upon evaluating the nutritional state of passion fruit seedlings fertilized with $\mathrm{N}$ and $\mathrm{K}$, Natale et al. (2006) found that $\mathrm{N}$ led to an increase in leaf concentrations of $\mathrm{N}, \mathrm{K}, \mathrm{P}$, and $\mathrm{S}$, and reduction in $\mathrm{Ca}$ and $\mathrm{Mg}$ concentration. Silva Júnior et al. (2013) observed that the addition of 22 and 33 g plant $^{-1}$ of $\mathrm{N}$ and $\mathrm{K}$ brought about higher leaf concentrations of $\mathrm{N}, \mathrm{K}$, and $\mathrm{Ca}$ and reduction in $\mathrm{Mg}$ concentration in sour passion fruit compared to the treatment fertilized with 11 and 16.5 g plant $^{-1}$ of $\mathrm{N}$ and $\mathrm{K}$, respectively.

The development of different passion fruit cultivars requires that studies be conducted to identify adequate leaf concentrations and nutrient contents in different parts of branches bearing fruit so as to increase the efficiency of nutritional diagnosis. Thus, the aim of this study was to evaluate the leaf concentrations and contents of macronutrients in different parts of branches bearing fruit of sour passion fruit cultivars under fertilization with $\mathrm{N}$ and $\mathrm{K}$.

\section{MATERIALS AND METHODS}

The study was conducted in the municipality of Janaúba, MG, in the period from April 2013 to April 2014. The location is $15^{\circ} 43^{\prime} 48^{\prime \prime} \mathrm{S}$ and $43^{\circ}$ $19^{\prime} 24^{\prime \prime} \mathrm{W}$ at $516 \mathrm{~m}$ altitude. Climate in the region is Aw according to the Köppen classification, that is, tropical climate with dry winter, and the soil of the experimental area is classified as a Latossolo Vermelho (EMBRAPA, 2013).

A randomized block experimental design was used, with three replications, and the experimental units were in a $4 \times 6$ factorial arrangement. This arrangement corresponds to four sour passion fruit cultivars (BRS Gigante Amarelo, IAC 275, BRS Ouro Vermelho, and BRS Sol do Cerrado) and six application rates of $\mathrm{N}-\mathrm{K}_{2} \mathrm{O}(0-0,50-125,100-250$, 150-375, 200-500, and 250-625 kg ha-1 year $\left.^{-1}\right)$. The average recommended application rate $(150-375$ $\mathrm{kg} \mathrm{ha}^{-1}$ year $^{-1}$ ) was estimated to obtain yield greater than $35 \mathrm{t} \mathrm{ha}^{-1}$ of fruit, according to Sousa and Borges (2011) for irrigated systems; however, with adaptations in regard to parceling out the fertilization and application of the fertilizers.

The sources of $\mathrm{N}$ and $\mathrm{K}$ used were urea, potassium chloride, and potassium sulfate, applied in topdressing and parceled out in four applications between two and eight months after planting; the first was carried out two months after planting and the others every two months afterwards. These fertilizers were diluted in $60 \mathrm{~L}$ of water, and $1 \mathrm{~L}$ of dilution was applied to each plant in a strip of approximately 0.2 $\mathrm{m}$ width around the trunk at a distance of $0.1 \mathrm{~m}$ from it up to 150 days after planting (DAP), increasing to $0.3 \mathrm{~m}$ from the trunk as of $180 \mathrm{DAP}$, according to 
Borges et al. (2003).

The experimental plots consisted of five plants at a spacing of $2.5 \times 2 \mathrm{~m}$ in a single row, and the three center plants were used for evaluation, for a total of $15 \mathrm{~m}^{2}$ of useful plot area. Before planting the passion fruit, the area had grown pineapple (July 2009 to October 2011), which had been fertilized with approximately $20 \mathrm{tha}^{-1}$ of cattle manure, 600 $\mathrm{kg} \mathrm{ha}^{-1}$ of $\mathrm{N}, 240 \mathrm{~kg} \mathrm{ha}^{-1}$ of $\mathrm{P}_{2} \mathrm{O}_{5}$, and $800 \mathrm{~kg} \mathrm{ha}^{-1}$ of $\mathrm{K}_{2} \mathrm{O}$. At the end of pineapple growing, the plant residues ( $30 \mathrm{t} \mathrm{ha}^{-1}$ dry matter) were left on the soil surface, and the area remained fallow for 18 months.

After that, the area was sprayed with glyphosate to eliminate weeds and form a new mulch. At that time, soil samples were collected from the area (at depths of 0-20 and 20-40 cm) for chemical and physical characterization of the soil (Table 1), according to the methods described by Embrapa (1997).

Soil tillage was performed in the experimental area in a conventional manner through plowing and two passes with a disk in preplanting. Seedlings of the passion fruit cultivars were produced in a nursery from seeds. Two seeds per plastic bag, containing 0.5 $\mathrm{L}$ of substrate, were used. Soon after germination, the seedlings were thinned, leaving only the seedling with greater vigor in each container. For preparation of $1 \mathrm{~m}^{3}$ of substrate, the following measures were adopted: the ratio of $3: 1: 1$ of soil, cattle manure, and sand, $5 \mathrm{~kg}$ of simple superphosphate, $1 \mathrm{~kg}$ of potassium chloride, $1 \mathrm{~kg}$ of dolomitic lime, and 50 $\mathrm{g}$ of FTE-BR12.

Two months after sowing, the seedlings had three pairs of defined leaves and were ready for planting. This was performed in April 2013 in plant holes of $0.4 \times 0.4 \times 0.4 \mathrm{~m}$. These holes were fertilized with $10 \mathrm{~L}$ of cattle manure, $100 \mathrm{~g}$ of dolomitic lime, $50 \mathrm{~g}$ of FTE-BR12, and $550 \mathrm{~g}$ of simple superphosphate. The cattle manure contained the following total nutrient concentrations: $0.90 \mathrm{dag}$ $\mathrm{kg}^{-1} \mathrm{~N} ; 0.12$ dag kg ${ }^{-1} \mathrm{P} ; 0.50$ dag kg-1 $\mathrm{K} ; 0.26$ dag kg $^{-1}$ $\mathrm{S} ; 0.58 \mathrm{dag} \mathrm{kg}^{-1} \mathrm{Ca}$, and $0.25 \mathrm{dag} \mathrm{kg}^{-1} \mathrm{Mg}$.

The crop was grown in a vertical trellis system with a wire to a height of $1.70 \mathrm{~m}$. The rows consisted of two posts at an angle of $30^{\circ}$ at the top and eight posts spaced at $5 \mathrm{~m}$ in the center of the row, with a total of 20 plant rows. The plants, after going beyond $10 \mathrm{~cm}$ above the wire, were pruned in order to break apical dominance, thus allowing emission of two new lateral branches, which were trained in opposite directions.

The lateral branches were trained until reaching $1 \mathrm{~m}$ on both sides and were then pruned to break apical dominance and favor the growth of productive branches. The productive branches were trained to a distance of $40 \mathrm{~cm}$ from the soil as a manner of preventing diseases caused by plant pathogens. Throughout the crop period, thinning was performed by pruning the stem and lateral branches, and growth, always maintaining a height of $40 \mathrm{~cm}$ above the ground.

The plants were irrigated by microspray nozzles with a flow of $120 \mathrm{~L} \mathrm{~h}^{-1}$, which were arranged in 10 rows at an approximate distance of $1 \mathrm{~m}$ from the root collar of the plants, with a total of 10 spray nozzles per row. Irrigation was applied according to crop needs, following the crop coefficient $(\mathrm{Kc})$ indicated by Silva and Klar (2002).

Weeds were controlled by application of glyphosate between the rows at the rate of $2 \mathrm{~L} \mathrm{ha}^{-1}$ in four applications throughout the crop season. Caterpillars and insects were controlled with pyrethroid and imidacloprid, respectively, at the

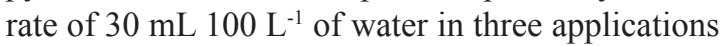
of pyrethroid and two of imidacloprid during the crop season.

Two methods of leaf sampling were adopted for nutritional characterization of the plants: taking leaves from the position adjacent to the fruit (adjacent leaf) and leaves from the end of the fruit-bearing branch (standard leaf). Leaves were sampled after flowering of the passion fruit plants, at approximately eight months after planting, collecting 20 leaves per experimental plot. The standard leaf was sampled according to Malavolta et al. (1997) through collecting the 4 th leaf of the vegetative branch, counting from the apex to the base of the branch. The method of sampling leaves from the adjacent position was adapted from Marchal and Bourdeaut (1972), collecting the leaves adjacent to the fruit in the initial phase of development (fruit of approximately $2 \mathrm{~cm}$ length), instead of sampling leaves at the axils of the flower buds.

The leaf samples were dried at $65^{\circ} \mathrm{C}$ in a forced air circulation oven for $72 \mathrm{~h}$ and ground in a Wiley mill for later determination of dry matter weight and macronutrient concentrations, according to Silva (2009). Based on nutrient concentration and on dry matter weight, the mean content of macronutrients in the leaves sampled from the passion fruit plants was calculated through the following equation:

In which:

$$
M C=\frac{\text { Concentration } x D M W}{100} \times f
$$


leaf $\left.{ }^{-1}\right)$

$\mathrm{MC}=$ macronutrient content in the leaf $(\mathrm{mg}$

Concentration $=$ macronutrient concentration in the leaf $\left(\right.$ dag $\left.\mathrm{kg}^{-1}\right)$;

$\mathrm{DMW}=$ leaf dry matter weight $\left(\mathrm{g} \mathrm{leaf}^{-1}\right)$;

$f=1000$, corresponds to the unit conversion factor (grams to milligrams).

The variables under study were subjected to analysis of variance $(\mathrm{p}<0.05)$. The qualitative factor (cultivars) was compared by the Tukey test $(\mathrm{p}<0.05)$ and the quantitative factor ( $\mathrm{N}$ and $\mathrm{K}$ application rates) was adjusted through regression analyses on the Sisvar statistical program (FERREIRA, 2011). The models were fitted based on the significance of the parameters and on the coefficient of determination.

\section{RESULTS AND DISCUSSION}

According to the results obtained after analysis of variance, the production of dry matter weight of the leaves and the leaf concentrations and content of $\mathrm{N}, \mathrm{P}, \mathrm{K}, \mathrm{Ca}, \mathrm{Mg}$, and $\mathrm{S}$ were significantly affected $(p<0.05)$ by the double interaction between the passion fruit cultivars versus $\mathrm{N}$ and $\mathrm{K}$ application rates, in both leaf sampling methods (Table 2).

In the adjacent leaf of the cultivars Ouro Vermelho and Sol do Cerrado, an increase was found in the content of dry matter weight with the increase in the N-K application rate up to 150 375 and 128-319 $\mathrm{kg} \mathrm{ha}^{-1}$, respectively (Figure 1). However, for the cultivar IAC 275, this characteristic decreased in a linear manner. In the cultivars Ouro Vermelho and Sol do Cerrado, the increase in leaf dry matter was related to a probable increase in leaf carbohydrate and protein synthesis, brought about by greater availability of $\mathrm{N}$ and $\mathrm{K}$ to plants after fertilization at intermediate application rates since these nutrients have specific functions in synthesis of carbohydrates and proteins (BORGES et al., 2002). However, in the cultivar IAC 275 , greater synthesis of organic compounds through N-K fertilization may have increased the number of vegetative leaves and branches, resulting in reduction in leaf dry matter with the increase in N-K application rates.

Among the cultivars studied, Gigante Amarelo and Ouro Vermelho had the greatest contents of N, P, K, Ca, Mg, and $\mathrm{S}$ in the adjacent leaf (Figures 2, 3, and 4), indicating their greater capacity for taking up these nutrients and possibly the greater nutritional demand of these cultivars. However, the lower content of $\mathrm{N}, \mathrm{P}, \mathrm{K}, \mathrm{Ca}$, and $\mathrm{Mg}$ in the leaves of cultivar IAC 275 in relation to the other cultivars is probably related to this cultivar having smaller leaves, with lower dry matter weight, which allows lower contents of nutrients.

The $\mathrm{N}$ concentrations in the standard leaf of the four passion fruit cultivars increased in a linear manner with the increase in the N-K application rate (Figure 2). The results of this study corroborate Natale et al. (2006), who upon working with nitrogen and potassium fertilization in sour passion fruit, observed that $\mathrm{N}-\mathrm{K}$ fertilization significantly increased the leaf $\mathrm{N}$ concentrations in passion fruit.

The content of $\mathrm{N}$ in the standard leaf increased only in the cultivars Ouro Vermelho and Sol do Cerrado (Figure 2). This indicates different $\mathrm{N}$ uptake capacities for the passion fruit plants. However, the lack of an increase in $\mathrm{N}$ content by the cultivars Gigante Amarelo and IAC 275 after fertilization with $\mathrm{N}$ and $\mathrm{K}$ can be explained by fertilization with cattle manure at planting in the plant hole and the initial (residual) availability of nutrients from organic matter $\left(2.9 \mathrm{dag} \mathrm{kg}^{-1}\right)$ and from the previous pineapple crop.

In the adjacent leaf, the highest $\mathrm{N}$ contents were obtained in the cultivars Gigante Amarelo and Ouro Vermelho (Figure 2), indicating their higher capacity for $\mathrm{N}$ uptake compared to the other cultivars. However, the responses of increase in $\mathrm{N}$ content after $\mathrm{N}-\mathrm{K}$ fertilization were not constant among the cultivars, and this can be explained by the high natural availability of $\mathrm{N}$ and $\mathrm{K}$ in the cultivated soil, as described above.

The $\mathrm{P}$ concentrations and contents in the adjacent and standard leaves for the passion fruit cultivars were not influenced by the proportions of $\mathrm{N}-\mathrm{K}$ fertilization, except for the cultivar IAC 275, in which the $\mathrm{P}$ leaf content decreased in a linear manner with the increase in N-K fertilizations (Figure 2). Nevertheless, the mean $\mathrm{P}$ concentration obtained in the standard leaf of the cultivars was considered adequate, according to Moraes et al. (2011) and Bataglia and Santos (2001). The latter authors state that the sufficiency range for $\mathrm{P}$ in the standard leaf is $0.15-0.25 \mathrm{dag} \mathrm{kg}^{-1}$ and in the adjacent leaf is 0.13 $0.21 \mathrm{dag}_{\mathrm{kg}}{ }^{-1}$.

The $\mathrm{K}$ concentrations in the standard and adjacent leaves of the passion fruit cultivars were considered adequate (Figure 3 ) according to the sufficiency ranges stated (2.0-3.0 and 2.2-2.7 dag $\mathrm{kg}^{-1}$ for standard and adjacent leaves, respectively) by Bataglia and Santos (2001). Carvalho et al. (2001), in the same crop, found that the K concentrations related to maximum yield are from 2.3 to $3.5 \mathrm{dag} \mathrm{kg}^{-1}$.

The leaf $\mathrm{K}$ concentrations and contents had a diverse response among the cultivars after the addition of the N-K application rates and sampling methods (Figure 3 ). The K concentration increased 
in a linear manner in the standard leaf of the Sol do Cerrado cultivar and in the leaf adjacent to the fruit in the cultivars IAC 275 and Ouro Vermelho. In the adjacent leaf of the Sol do Cerrado cultivar, a quadratic increase was obtained in the $\mathrm{K}$ concentration, with higher mean values in the intermediate proportions of N-K fertilization (113-281 and 150-375 $\mathrm{kg} \mathrm{ha}^{-1}$ of applied $\mathrm{N}$ and $\mathrm{K}$, respectively). In the other cultivars, no effect was observed from $\mathrm{N}-\mathrm{K}$ fertilization on leaf $\mathrm{K}$ concentration and content. These results were brought about by the high exchangeable $\mathrm{K}$ concentration in the soil of the experimental area (156 $\mathrm{mg} \mathrm{dm}^{-3}$ in the $0-20 \mathrm{~cm}$ depth layer).

Various studies have reported a positive effect on $\mathrm{K}$ uptake after $\mathrm{K}$ fertilization (SOUSA et al., 2008; MORAES et al., 2011; ALMEIDA, 2012). Nevertheless, an increase in $\mathrm{K}$ leaf concentrations after $\mathrm{K}$ fertilization does not necessarily imply an increase in yield. Borges et al. (2003) found a null or negative effect from the use of $\mathrm{K}$ application rates $\left(0,200,400,800\right.$, and $1600 \mathrm{~kg} \mathrm{ha}^{-1}$ year $^{-1}$ of $\left.\mathrm{K}_{2} \mathrm{O}\right)$ on yield, notably from the addition of $400 \mathrm{~kg} \mathrm{ha}^{-1}$ of $\mathrm{N}$, and the lack of effect of $\mathrm{K}$ on fruit quality.

The concentration and content of $\mathrm{Ca}$ in the adjacent leaf decreased in a linear manner with the increase in the $\mathrm{N}-\mathrm{K}$ proportions in the cultivars Gigante Amarelo, IAC 275, and Ouro Vermelho (Figure 4), and the leaf concentrations obtained in the cultivars were considered adequate according to the sufficiency range (1.2-1.6 dag kg-1) described by Bataglia and Santos (2001). In the standard leaf, reduction in $\mathrm{Ca}$ leaf concentration with the increase in N-K fertilization was observed only in the cultivars IAC and Ouro Vermelho (Figure 4). However, these concentrations were below the ideal condition (1.7$2.7 \mathrm{dag} \mathrm{kg}^{-1}$ ) in all the cultivars.

In general, higher concentrations and contents of Ca were observed in the leaves of the treatments that did not receive the N-K fertilizations (control). Results in the literature indicate the competitive effect among these cations for the same uptake sites (AULAR et al., 2014). Higher K fertilization rates inhibited $\mathrm{Ca}$ uptake. In this experiment, the results are in agreement with those found by Sousa et al. (2008), who found the highest $\mathrm{Ca}$ concentrations in the treatments that did not receive $\mathrm{K}$ application. Carvalho et al. (2002) studied the effects of nitrogen fertilization and of irrigation on the nutrient concentrations in the leaves of sour passion fruit plants in different seasons and found that there was a decrease in Ca concentrations with an increase in $\mathrm{N}$ application rates, probably due to the competition between the $\mathrm{NH}_{4}^{+}$ion coming from urea hydrolysis. $\mathrm{Ca}$ uptake by plants is directly associated with the $\mathrm{K}$ and $\mathrm{Mg}$ concentrations in the soil solution, indicating that uptake of these cations by plants is governed by the equilibrium of exchangeable bases (MALAVOLTA, 1981).

The Mg concentrations in the standard leaf of the cultivars IAC 275 and Ouro Vermelho and the $\mathrm{Mg}$ contents in the adjacent leaf of the cultivars Gigante Amarelo, IAC 275, and Ouro Vermelho declined with the increase in the proportions of $\mathrm{N}-\mathrm{K}$ fertilization (Figure 4). In the Sol do Cerrado cultivar, the leaf $\mathrm{Mg}$ contents were not affected by fertilization. Nevertheless, all the passion fruit cultivars had $\mathrm{Mg}$ concentrations in the standard and adjacent leaves below the sufficiency range $(0.30$ 0.40 and $0.25-0.31 \mathrm{dag}^{\mathrm{kg}}{ }^{-1}$ for the standard and adjacent leaves, respectively) described by Bataglia and Santos (2001).

The reduction in leaf $\mathrm{Mg}$ concentrations after the increase in proportions of $\mathrm{N}-\mathrm{K}$ fertilization was also attributed to the competitive effect with the $\mathrm{K}$ cation by the uptake sites and movement within the plant, because $\mathrm{Mg}$ is a nutrient that competes with the $\mathrm{Ca}^{++}$and $\mathrm{K}^{+}$cations for the same uptake sites (CARVALHO et al., 2001). Sousa et al. (2008) found that higher uptake of $\mathrm{Ca}$ and $\mathrm{Mg}$ by passion fruit occurred in the absence of or with low application rates of K. Cavalcante et al. (2012) evaluated the leaf macronutrient concentrations in sour passion fruit after addition of biofertilizers and NPK and observed reduction in the $\mathrm{Mg}$ concentrations and attributed this effect to the competition that exists between $\mathrm{K}, \mathrm{Ca}$, and $\mathrm{Mg}$ on the membrane level.

The $\mathrm{S}$ concentrations in the adjacent or standard leaves were not affected by N-K fertilization for the cultivars Gigante Amarelo and Ouro Vermelho, but in the cultivars IAC 275 and Sol do Cerrado, the intermediate fertilization proportions (113-281 and 150-375 $\mathrm{kg} \mathrm{ha}^{-1}$ of applied $\mathrm{N}$ and $\mathrm{K}$, respectively) provided for a greater concentration and content of S in the standard leaf (Figure 3). The mean concentrations of $\mathrm{S}$ found in the standard leaf of the cultivars under study are near those found by Carvalho et al. (2001) and Borges et al. (2002). These authors observed mean concentrations of $\mathrm{S}$ ranging from $0.29 \mathrm{a} 0.32 \mathrm{dag} \mathrm{kg}^{-1}$ in the first year of the passion fruit crop.

The leaf macronutrient concentrations and contents showed differentiated responses for each cultivar, sampling method, and proportions of N-K fertilization. The standard leaf is physiologically more active and acts as a nutrient sink. It thus exhibited the highest concentrations and variations in macronutrients. However, the highest contents occurred in the leaf adjacent to the fruit due to its 
greater weight and advanced stage of maturity. Among the cultivars studied, Gigante Amarelo and Ouro Vermelho exhibited the highest contents of $\mathrm{N}$,
$\mathrm{P}, \mathrm{K}, \mathrm{Ca}, \mathrm{Mg}$, and $\mathrm{S}$ in the adjacent leaf, indicating greater demand for N-K at different proportions, which requires the management practice of different diagnosis for each cultivar.

TABLE 1- Chemical and physical composition of soil samples collected at the depths of $0-20$ and 20-40 cm. Janaúba, MG, Brazil. 2014.

\begin{tabular}{|c|c|c|c|c|c|c|c|c|c|c|c|c|}
\hline Depth & $\mathrm{pH}^{1}$ & $\mathrm{OM}^{2}$ & $\mathrm{P}^{3}$ & $\mathrm{~K}^{3}$ & $\mathrm{Na}^{3}$ & $\mathrm{Ca}^{4}$ & $\mathrm{Mg}^{4}$ & $\mathrm{Al}^{4}$ & $\mathrm{H}+\mathrm{Al}^{5}$ & SB & $\mathrm{t}$ & $\mathrm{T}$ \\
\hline $\mathrm{cm}$ & & dag $\mathrm{kg}^{-1}$ & \multicolumn{10}{|c|}{$--\mathrm{mg} \mathrm{dm}^{-3}--$} \\
\hline $0-20$ & 5.9 & 2.9 & 3.9 & 156.0 & 0.1 & 3.0 & 1.2 & 0.0 & 1.3 & 4.7 & 4.7 & 6.0 \\
\hline $20-40$ & 5.4 & 1.4 & 3.6 & 95.0 & 0.2 & 2.6 & 0.8 & 0.0 & 1.3 & 3.8 & 3.8 & 5.1 \\
\hline Depth & $\mathrm{V}$ & $\mathrm{m}$ & $\mathrm{B}^{6}$ & $\mathrm{Cu}^{3}$ & $\mathrm{Fe}^{3}$ & $\mathrm{Mn}^{3}$ & $\mathrm{Zn}^{3}$ & P-rem ${ }^{8}$ & $\mathrm{EC}$ & Sand & Silt & Clay \\
\hline $\mathrm{cm}$ & \multicolumn{2}{|c|}{---- \% ---- } & \multicolumn{5}{|c|}{------- $\mathrm{mg} \mathrm{dm}^{-3}$--------- } & $\mathrm{mg} \mathrm{L}^{-1}$ & $\mathrm{dS} \mathrm{m}^{-1}$ & \multicolumn{3}{|c|}{------- dag kg kg $^{-1}$} \\
\hline $0-20$ & 78.0 & 0.0 & 0.3 & 1.4 & 25.6 & 8.6 & 0.7 & 36.1 & 0.7 & 64 & 9 & 27 \\
\hline $20-40$ & 74.0 & 0.0 & 0.3 & 1.1 & 26.8 & 5.9 & 0.6 & 35.5 & 0.6 & 55 & 9 & 36 \\
\hline
\end{tabular}

${ }^{1} \mathrm{pH}$ in water; ${ }^{2}$ Colorimetry; ${ }^{3}$ Extractant: Mehlich- $1 ;{ }^{4}$ Extractant: $1 \mathrm{~mol} \mathrm{~L}-1 \mathrm{KCl} ;{ }^{5} \mathrm{pH}$ SMP; ${ }^{6}$ Extractant: $\mathrm{BaCl}_{2} ;{ }^{8}$ Equilibrium solution of P. SB, Sum of bases; t, effective CEC; T, CEC at pH 7; V, Base saturation; m, Aluminum saturation; P-rem, Remaining phosphorus; EC, Electrical conductivity.

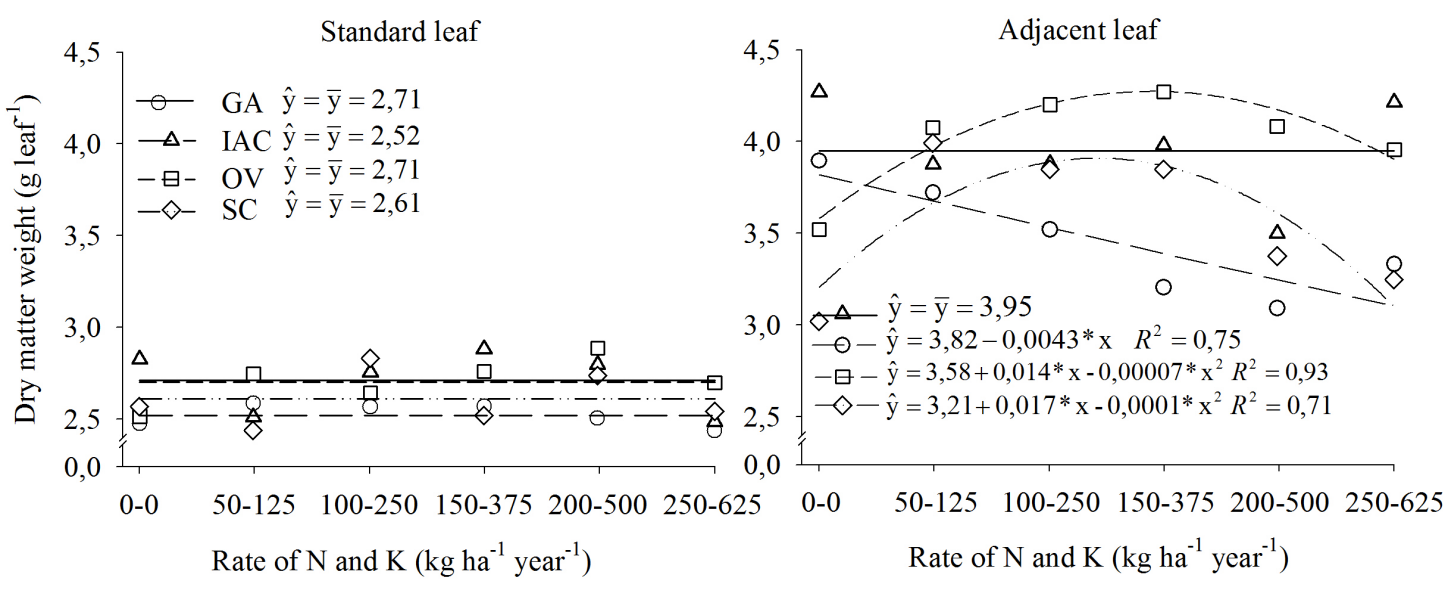

FIGURE 1-Mean of dry matter weight of the leaf collected from the position adjacent to the fruit (adjacent leaf) and 4th leaf of the fruit-bearing branch (standard leaf) of passion fruit cultivars under fertilization with application rates of $\mathrm{N}$ and $\mathrm{K}$, through the soil. *: significant at $5 \%$ probability. Janaúba, MG, Brazil. 2014. 
TABLE 2-Summary of analysis of variance of the data referring to dry matter weight (DM), concentration and content of $\mathrm{N}$ ( $\mathrm{NC}$ and $\mathrm{NA}$ ), $\mathrm{P}$ ( $\mathrm{PC}$ and $\mathrm{PA}), \mathrm{K}$ ( $\mathrm{KC}$ and $\mathrm{KA}), \mathrm{Ca}(\mathrm{CaC}$ and $\mathrm{CaA}), \mathrm{Mg}$ ( $\mathrm{MgC}$ and $\mathrm{MgA}$ ), and $\mathrm{S}$ (SC and $\mathrm{SA}$ ) in the standard and adjacent leaves of passion fruit plants (Cultivar) fertilized with N and K application rates. Janaúba, MG, Brazil. 2014.

\begin{tabular}{|c|c|c|c|c|c|c|c|c|}
\hline \multirow[b]{2}{*}{ SV } & \multicolumn{8}{|c|}{ MS (Standard leaf) } \\
\hline & $\mathrm{DF}$ & DM & $\mathrm{NC}$ & $\mathrm{PC}$ & $\mathrm{KC}$ & $\mathrm{CaC}$ & $\mathrm{MgC}$ & $\mathrm{SC}$ \\
\hline Block & 2 & $0.7849 *$ & $0.1836^{*}$ & $0.0033 *$ & $0.2440^{\mathrm{ns}}$ & $0.1292 *$ & $0.0014^{\mathrm{ns}}$ & $0.0264 *$ \\
\hline Cultivar (C) & 3 & $1.5795^{*}$ & $0.1611 *$ & $0.0029 *$ & $0.0668^{\text {ns }}$ & $0.0873^{\text {ns }}$ & $0.0030 *$ & $0.0041 *$ \\
\hline Rate of N and K (D) & 5 & $0.2328^{*}$ & $0.3020^{*}$ & $0.0020 *$ & $0.1424^{\mathrm{ns}}$ & $0.1565^{*}$ & $0.0028 *$ & $0.0047 *$ \\
\hline C versus D & 15 & $0.3018^{*}$ & $0.1741^{*}$ & $0.0018^{*}$ & $0.6405^{*}$ & $0.0939 *$ & $0.0020^{*}$ & $0.0022 *$ \\
\hline Residue & 16 & 0.0587 & 0.0419 & 0.0007 & 0.2292 & 0.0339 & 0.0005 & 0.0006 \\
\hline$\overline{C V(\%)}$ & & 6.50 & 5.48 & 9.78 & 10.61 & 14.13 & 15.75 & 7.18 \\
\hline SV & $\mathrm{DF}$ & & NA & PA & KA & $\mathrm{CaA}$ & $\mathrm{MgA}$ & SA \\
\hline Block & 2 & & $13.9624^{*}$ & $0.0050^{\text {ns }}$ & $177.3379 *$ & $0.2463^{\text {ns }}$ & $0.0015^{\text {ns }}$ & $0.5150^{*}$ \\
\hline Cultivar (C) & 3 & & $64.1655^{*}$ & $0.4740 *$ & $55.6382 *$ & $3.1107^{\mathrm{ns}}$ & $0.2815^{*}$ & $0.7956^{*}$ \\
\hline Rate of $\mathrm{N}$ and $\mathrm{K}$ (D) & 5 & & $22.7842 *$ & $0.2628 *$ & $32.8474^{\mathrm{ns}}$ & $12.6371 *$ & $0.1911 *$ & $0.6203^{*}$ \\
\hline$C$ versus D & 15 & & $17.6151^{*}$ & $0.1996^{*}$ & $77.1396^{*}$ & $9.9536^{*}$ & $0.1387 *$ & $0.1607 *$ \\
\hline Residue & 16 & & 6.8091 & 0.0735 & 20.0039 & 3.2891 & 0.0382 & 0.0624 \\
\hline \multirow[t]{2}{*}{$\mathrm{CV}(\%)$} & & & 7.95 & 10.79 & 11.25 & 15.86 & 14.94 & 8.31 \\
\hline & \multicolumn{8}{|c|}{ MS (Adjacent leaf) } \\
\hline SV & $\mathrm{DF}$ & DM & $\mathrm{NC}$ & $\mathrm{PC}$ & $\mathrm{KC}$ & $\mathrm{CaC}$ & $\mathrm{MgC}$ & $\mathrm{SC}$ \\
\hline Block & 2 & $0.3742 *$ & $0.4533 *$ & $0.0004^{\text {ns }}$ & $0.2360^{\text {ns }}$ & $0.3252 *$ & $0.0013 *$ & $0.0018^{*}$ \\
\hline Cultivar (C) & 3 & $0.1447 *$ & $0.0945^{*}$ & $0.0002^{\mathrm{ns}}$ & $2.3427^{*}$ & $0.2178 *$ & $0.0013 *$ & $0.0014^{*}$ \\
\hline Rate of N and K (D) & 5 & $0.0730 *$ & $0.4219^{*}$ & $0.0003^{\mathrm{ns}}$ & $1.4831^{*}$ & $0.2549 *$ & $0.0012 *$ & $0.0010^{*}$ \\
\hline$C$ versus D & 15 & $0.0453 *$ & $0.2074 *$ & $0.0010^{*}$ & $0.6240^{*}$ & $0.1269 *$ & $0.0005^{*}$ & $0.0009 *$ \\
\hline Residue & 16 & 0.0131 & 0.0328 & 0.0004 & 0.2294 & 0.0504 & 0.0001 & 0.0003 \\
\hline $\mathrm{CV}(\%)$ & & 4.34 & 5.78 & 12.57 & 11.34 & 12.40 & 10.49 & 5.89 \\
\hline SV & $\mathrm{DF}$ & & NA & PA & KA & $\mathrm{CaA}$ & $\mathrm{MgA}$ & SA \\
\hline$\overline{\text { Block }}$ & 2 & & $0.4880^{\text {ns }}$ & $0.0798^{\text {ns }}$ & $37.5529^{\mathrm{ns}}$ & $2.6230^{\text {ns }}$ & $0.0108^{\text {ns }}$ & $0.7510^{*}$ \\
\hline Cultivar (C) & 3 & & $266.4530^{*}$ & $0.6226^{*}$ & $987.1489 *$ & $71.4446^{*}$ & $0.7953 *$ & $2.0008^{*}$ \\
\hline Rate of $N$ and $K$ (D) & 5 & & $25.9230 *$ & $0.0503^{\mathrm{ns}}$ & $247.9314^{*}$ & $80.4798 *$ & $0.2992 *$ & $0.3571 *$ \\
\hline$C$ versus D & 15 & & $44.8680 *$ & $0.2155^{*}$ & $161.5764 *$ & $37.9059 *$ & $0.0986^{*}$ & $0.3628 *$ \\
\hline Residue & 16 & & 9.0200 & 0.0852 & 43.3424 & 12.2836 & 0.0220 & 0.0606 \\
\hline$\overline{C V(\%)}$ & & & 7.73 & 14.03 & 12.51 & 15.55 & 11.04 & 6.60 \\
\hline
\end{tabular}

ns - not significant, ${ }^{*}$ - significant at $5 \%$ probability by the $\mathrm{F}$ test 


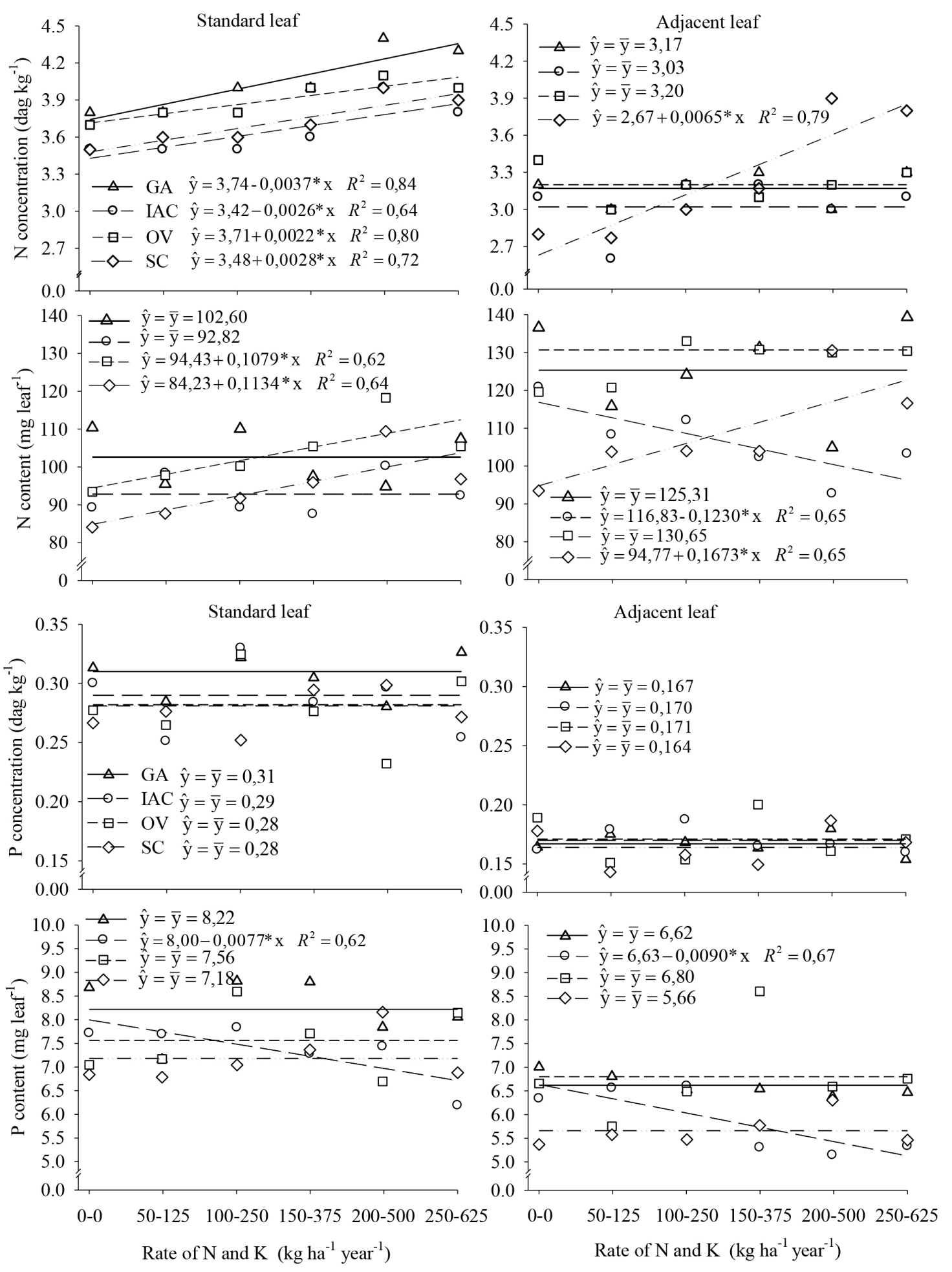

FIGURE 2- Concentration and content of $\mathrm{N}$ and $\mathrm{P}$ in leaf samples collected from the position adjacent the fruit (adjacent leaf) and at the end of the fruit-bearing branch (standard leaf) of passion fruit plants under fertilization with application rates of $\mathrm{N}$ and $\mathrm{K}$ through the soil. *: significant at 5\% probability. Janaúba, MG, Brazil. 2014. 

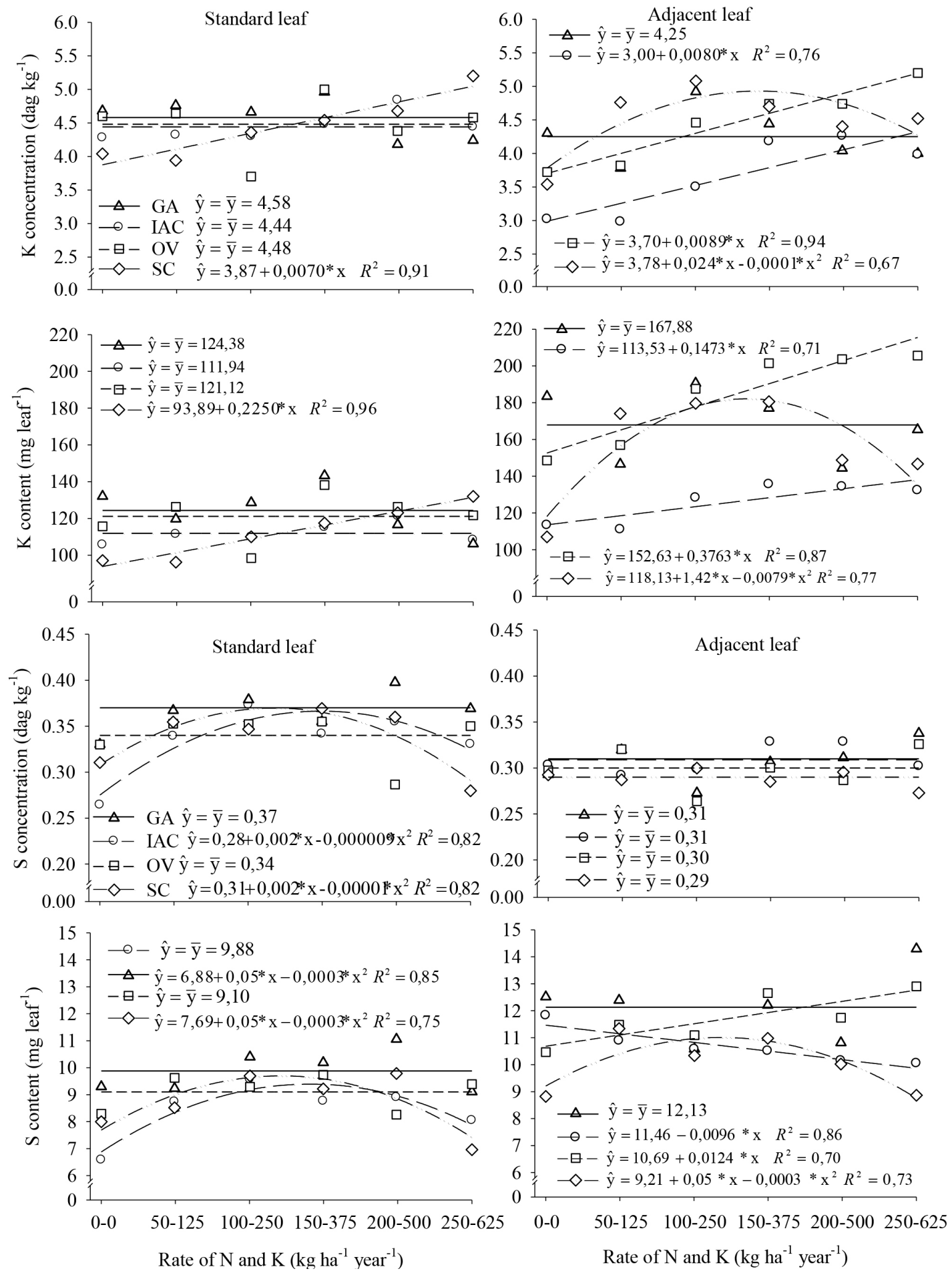

FIGURE 3- Concentration and content of $\mathrm{K}$ and $\mathrm{S}$ in leaf samples collected from the position adjacent to the fruit (adjacent leaf) and at the end of the fruit-bearing branch (standard leaf) of passion fruit plants under fertilization with application rates of $\mathrm{N}$ and $\mathrm{K}$ through the soil. *: significant at 5\% probability. Janaúba, MG, Brazil. 2014. 

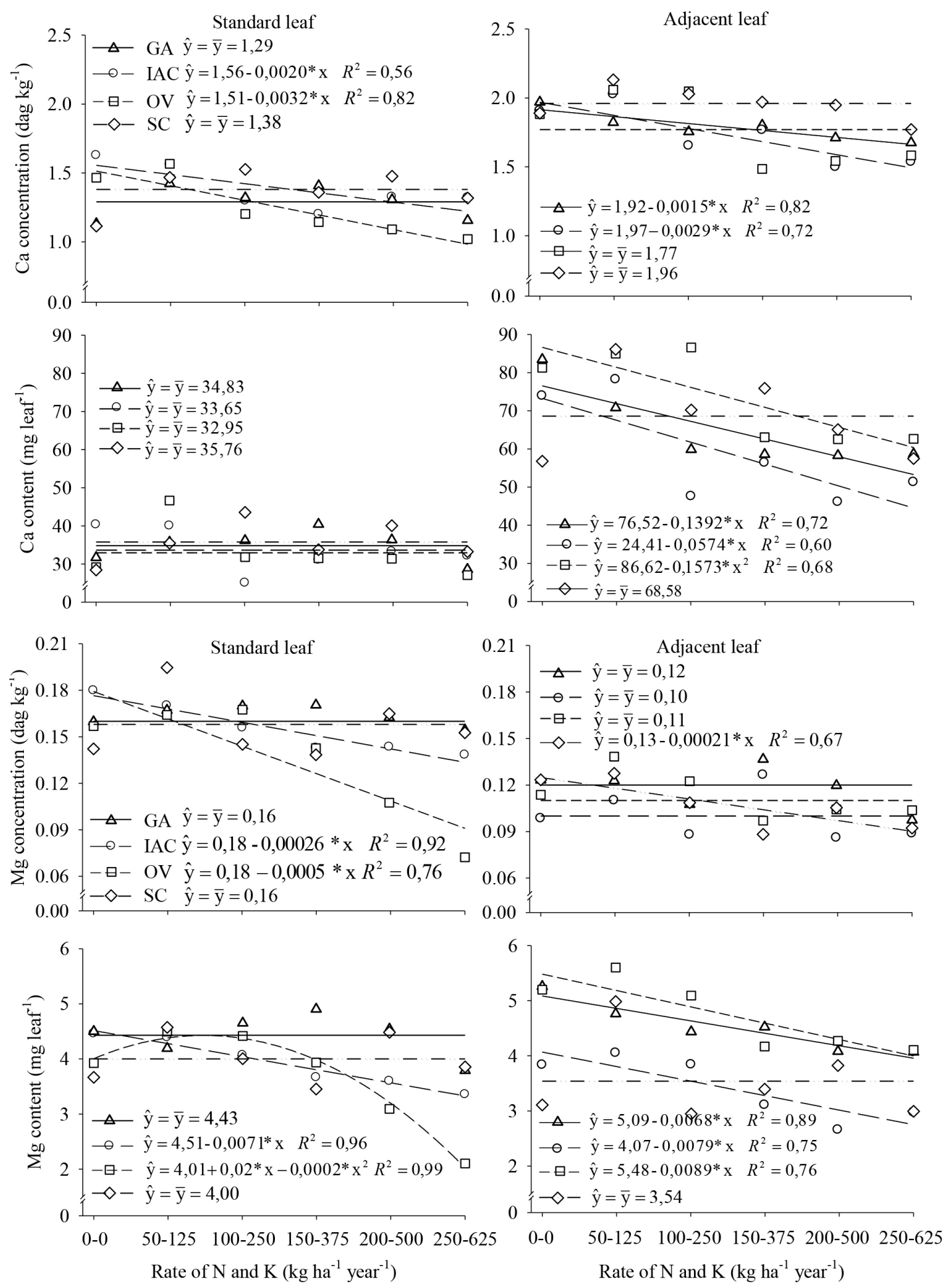

FIGURE 4-Concentration and content of $\mathrm{Ca}$ and $\mathrm{Mg}$ in leaf samples collected from the position adjacent to the fruit (adjacent leaf) and at the end of the fruit-bearing branch (standard leaf) of passion fruit plants under fertilization with application rates of $\mathrm{N}$ and $\mathrm{K}$ through the soil. *: significant at 5\% probability. Janaúba, MG, Brazil. 2014. 


\section{CONCLUSIONS}

The passion fruit cultivars Ouro Vermelho and Gigante Amarelo have higher leaf contents of $\mathrm{N}, \mathrm{P}, \mathrm{K}, \mathrm{Ca}$, and $\mathrm{Mg}$ than the cultivars Sol do Cerrado and IAC 275.

Intermediate application rates of $\mathrm{N}$ (from 113 to $150 \mathrm{~kg} \mathrm{ha}^{-1}$ ) and $\mathrm{K}$ (from 281 to $375 \mathrm{~kg} \mathrm{ha}^{-1}$ ) increase the $\mathrm{K}$ concentration in the adjacent leaf of the Sol do Cerrado cultivar.

The increase in the N-K proportions raises the $\mathrm{N}$ concentrations in the standard leaf in the cultivars Gigante Amarelo, IAC 275, Ouro Vermelho, and Sol do Cerrado and $\mathrm{N}$ content in the adjacent and standard leaves of the Ouro Vermelho cultivar.

The increase in N-K proportions reduces the concentrations and contents of $\mathrm{Ca}$ and $\mathrm{Mg}$ and increases those of $\mathrm{K}$ in most of the leaves of the cultivars evaluated.

\section{ACKNOWLEDGMENTS}

The authors thank the Foundation for Research Support of Minas Gerais (FAPEMIG), National Council for Scientific and Technological Development (CNPq) and Pro-Rectory Research of Federal University de Minas Gerais (PRPq-UFMG) for financial and scholarship support. We also thank the CNPq for the Research Productivity Grant to the first and fourth author.

\section{REFERENCES}

ALMEIDA, R.F. Nutrição de Maracujazeiro. Revista Verde de Agroecologia e Desenvolvimento Sustentável, Mossoró, v.7, n.3, p.12-17, 2012.

AULAR, J.; CASARES, M.; NATALE, W. Mineral nutrition and fruit quality of pineaple and passion fruit. Revista Brasileira de Fruticultura, Jaboticabal, v.36, n.4, p.1046-1054, 2014.

BATAGLIA, O.C.; SANTOS, W.R.D. Estado nutricional de plantas perenes: avaliação e monitoramento. Informações Agronômicas, São Paulo, v.96, p.3-8, 2001.

BORGES, A.L.; CALDAS, R.C.; LIMA, A.A.; ALMEIDA, I.E. Efeito de doses de NPK sobre os teores de nutrientes nas folhas e no solo, e na produtividade do maracujazeiro amarelo. Revista Brasileira de Fruticultura, Jaboticabal, v.24, n.1, p.208-213, 2002.
BORGES, A.L; RODRIGUES, M.G.; LIMA, A.A.; ALMEIDA, I.E.; CALDAS, R.C. Produtividade e qualidade de maracujá-amarelo irrigado, adubado com nitrogênio e potássio. Revista Brasileira de Fruticultura, Jaboticabal, v.25, n.2, p.259-262, 2003.

CARVALHO, A.J.C.; MARTINS, D.P.; MONNERAT, P.H.; BERNARDO, S.; SILVA, J.A.Teores de nutrientes foliares no maracujazeiroamarelo associado à estação fenológica, adubação potássica e lâmina de irrigação.Revista Brasileira de Fruticultura, Jaboticabal, v.23, n.2, p.403-408, 2001.

CARVALHO,A.J.C.; MONNERAT, P.H.; MARTINS, D.P.; BERNARDO, S.; SILVA, J.A. Teores foliares de nutrientes no maracujazeiro amarelo em função de adubação nitrogenada, irrigação e épocas de amostragem. Scientia Agricola, Piracicaba, v.59, n.1, p.121-127, 2002.

CAVALCANTE, L.F.; CAVALCANTE, I.H.L.; RODOLFO JÚNIOR, F.; BECKMANNCAVALCANTE, M.Z.; SANTOS, G.P. Leafmacronutrient status and fruit yield of biofertilized yellow passion fruit plants. Journal of Plant Nutrition, Monticello, v.35, n.1, p.176-191, 2012.

EMBRAPA. Manual de métodos de análise de solo. 2.ed. Rio de Janeiro: Centro Nacional de Pesquisa de Solos, 1997. 212p.

EMBRAPA. Sistema brasileiro de classificação de solos. 3.ed. Brasília, 2013. 353p.

FERREIRA, D.F. Sisvar: a computer statistical analysis system. Ciência \& Agrotecnologia, Lavras, v.35, n.6, p.1039-1042, 2011.

FREITAS, M.S.M.; MONNERAT P.H.; VIEIRA I.J.C.; CARVALHO A.J.C. Flavonóides e composição mineral de folhas de maracujazeiro amarelo em função da posição da folha no ramo. Ciência Rural, Santa Maria, v.37, n.6, p.1634-1639, 2007.

FREITAS, M.S.M.; MONNERAT, P.H.; CARVALHO, A.J.C.; VASCONCELLOS, M.A.S. Sintomas visuais de deficiência de macronutrientes e boro em maracujazeiro-doce. Revista Brasileira de Fruticultura, Jaboticabal, v.33, n.4, p.1329-1341, 2011. 
FREITAS, M.S.M.; MONNERAT, P.H.; PINHO, L.G.R.; CARVALHO, A.J.C. Deficiência de macronutrientes e boro em maracujazeiro doce: qualidade dos frutos. Revista Brasileira de Fruticultura, Jaboticabal, v.28, n.3, p.492-496, 2006.

IBGE - Instituto Brasileiro de Geografia e Estatística. Produção agrícola municipal: culturas temporárias e permanentes. Rio de Janeiro, 2014. v.41, p.1-99.

MALAVOLTA, E. Manual de química agrícola: adubos e adubação. 3.ed. São Paulo: Agronômica Ceres, 1981. 596p.

MALAVOLTA, E.; VITTI, G.C.; OLIVEIRA, S.A. Avaliação do estado nutricional das plantas: princípios e aplicações. 2.ed. Piracicaba: Associação Brasileira para Pesquisa da Potassa e do Fosfato, 1997. $319 \mathrm{p}$.

MARCHAL, J.; BOURDEAUT, J. Leaf sampling of passionfruit (Passiflora edulis Sims.var.flavicarpa). Fruits, Paris, v.27, p.307-311, 1972.

MORAES, J.C.B.; SALCEDO, I.H.; SOUSA, V.F. Doses de potássio por gotejamento no estado nutricional do maracujazeiro. Revista Brasileira de Engenharia Agrícola e Ambiental, Campina Grande, v.15, n.8, p.763-770, 2011.

NATALE, W; PRADO, R.M.; ALMEIDA, E.V.; BARBOSA, J.C. Adubação nitrogenada e potássica no estado nutricional de mudas de maracujazeiroamarelo. Acta Scientiarum.Agronomy, Maringá, v.28, n.2, p.187-192, 2006.

SANTOS, P.C.; LOPES, L.C.; FREITAS, S.J.; SOUSA, L.B.; CARVALHO, A.J.C. Crescimento inicial e teor nutricional do maracujazeiro amarelo submetido à adubação com diferentes fontes nitrogenadas. Revista Brasileira de Fruticultura, Jaboticabal, v.33, n.1, p.722-728, 2011.
SILVA JÚNIOR, G.B.; CAVALCANTE, Í.H.L.; ALBANO, F.G.; OSAJIMA, J.A. Estado nutricional e clorofila foliar do maracujazeiro-amarelo em função de biofertilizantes, calagem e adubação com N e K. Revista de Ciências Agrárias, v.36, n.2, p.163-173, 2013.

SILVA, A.A.G.; KLAR, A.E. Demanda hídrica do maracujazeiro amarelo (Passiflora edulis Sims f.flavicarpa Deg.). Irriga, Botucatu, v.7, n.3, p.185190, 2002

SILVA, F.C.D.S. Manual de análises químicas de solos, plantas e fertilizantes. 2.ed. Brasília, DF: Embrapa Informação Tecnológica, 2009. 627 p.

SOUSA, L.B.; HEITOR, L.C.; SANTOS, P.C.; FREITAS, J.A.A.; FREITAS, M.S.M.; FREITAS, S.J.; CARVALHO, A.J.C. Crescimento, composição mineral e fenóis totais de espécies de Passiflora em função de fontes nitrogenadas. Bragantia, Campinas, v.72, n.3, p.247-254, 2013.

SOUSA, V.F.; BORGES, A.L. Irrigação e fertirrigação na cultura do maracujá. In: SOUSA, V.F.; MAROUELLI, W.A.; COELHO, E.F.; PINTO, J.M.; COELHO FILHO, M.A. (Ed.). Irrigação e fertirrigação em fruteiras e hortaliças. Brasília, DF: Embrapa Informação Tecnológica, 2011. cap.17, p.501-522.

SOUSA, V.F.; FOLEGGATTI, M.V.; FRIZZONE.J.A.; DIAS, T.J.; ALBUQUERQUE JÚNIOR, B.S.; BATISTA, E.C. Níveis de irrigação e doses de potássio sobre os teores foliares de nutrientes do maracujazeiro amarelo. Revista Brasileira de Engenharia Agrícola e Ambiental, Campina Grande, v.12, n.1, p.41-46, 2008.

TAIZ, L.; ZEIGER, E. Fisiologia vegetal. 5.ed. Porto Alegre: Artmed, 2013. 954 p. 